\title{
Production of microbial keratinase using a newly isolated strain of Stenotrophomonas maltophilia and its characterization and applications.
}

\author{
Bhavika N. Parmar, Dr. Sneha H. Trivedi * \\ Shree Ramkrishna Institute of Computer Education \& Applied Sciences \\ B/H P.T. Science College, M.T.B. College Campus, Athwalines, \\ Surat-395001, Gujarat, India \\ *Corresponding Author: Email: sneha15380@gmail.com
}

\begin{abstract}
Biodegradation of keratin containing wastes viz. bird feathers, nails, hairs, animalwool is a low-cost, nutrient-rich biotechnological process that turns this plentiful waste into a low-cost, nutrient-rich substance. It is a sustainable green approach towards the solution of environmental threats created by these wastes. This study aimed to screen for potential keratinase-producing microorganisms and to optimize physicochemical parameters to produce keratinase and its characterization. Samples were collected from various poultry farms of Surat (India). Screening for keratinase-production was carried using a feather basal medium. Among these samples, 16 isolates showed keratinolytic activity in primary screening using skim milk agar medium among which, nine isolates showed keratinolytic activity using keratin agar medium. Isolate $\mathrm{KA}_{1}$ a gave the highest yield of keratinase and was identified as a strain of Stenotrophomonas maltophilia (NCBI Accession number MT478451), based on 16S rRNA sequencing. It delivered highest enzyme production $(108 \mathrm{U} / \mathrm{ml})$ in the medium with feathers $(2.2 \%), \mathrm{NaCl}(0.5 \%), \mathrm{K}_{2} \mathrm{HPO}_{4}(0.3 \%), \mathrm{KH}_{2} \mathrm{PO}_{4}(0.4 \%), \mathrm{pH} 7$, with $10 \%$ inoculum of young cell mass, at $37^{\circ} \mathrm{C}$ for $24 \mathrm{~h}$ under shaking conditions. Optimum temperature for keratinase activity was $40^{\circ} \mathrm{C}$ and $\mathrm{pH}$ 7.0. Enzyme showed stability over different temperature and $\mathrm{pH}$ for up to 90 min. It showed potential applications as a detergent additive, animal feed, and organic fertilizer.
\end{abstract}

Keywords: Chicken feathers; keratinase; optimization; Stenotrophomonas maltophilia.

\section{Introduction}

The increased use of chicken, duck, and goose meat is having a negative impact on mother nature, as the feather waste generated from those chicks is not being properly degraded. Natural decay of feathers is slower, resulting in sulfurous substances that are harmful to the environment. Feathers generated in enormous volume in the form of by-product of poultry industries tends to be the store house of keratin (Adelere \& Lateef, 2016). Keratin is the major component of feathers and is resistant to proteolytic enzymes namely papain, trypsin and pepsin.
Keratin persists as a structural component of vertebrate skin, hairs, feathers and other exoskeletons (Feughelman, 1985).

On the basis of their secondary structural conformations, keratin proteins are grouped as $\alpha$ helices (hair and wool) and $\beta$ sheets(feathers) (Akhtar \& Edwards, 1997).

Keratinase [E.C.3.4.21/24/99.11] proteases enzymes able to degrade the scleroprotein keratin. They are robust enzymes that work well at a number of 
different temperatures and $\mathrm{pH}$ levels, with optimal activity near neutral to alkaline $\mathrm{pH}$ and temperature ranging between 40 and $70^{\circ} \mathrm{C}$. These enzymes are also active over a variety of proteinic substrates such as keratin, fibrin, gelatin, and casein (Gupta \& Ramnani, 2006; Lateef et al., 2010). Keratinases are produced by bacteria, actinomycetes, and fungi which can hydrolysate a large number of keratin substrates (Tork et al., 2010; Saibabu et al., 2013).

Majority of feather-degrading bacterial isolates belong to gram-positive category of Bacillus spp. which includes Bacillus subtilis, Bacillus cereus, etc. (Adiguzal et al., 2009; Kumar et al., 2010). Keratinolytic bacteria that are gram negative, are the members of Xanthomonas spp., Stenotrophomonas spp. etc. (De Toni et al., 2002; Yamamura et al., 2002). Keratin hydrolysate can be used in the medical fields, as animal feed, and addition as fertilizer, and as a detergent. The present study was aimed to isolate, identify, optimize and characterize the keratin degrading microorganisms from poultry farm soil and study their applications.

\section{Materials and Methods}

\subsection{Sample collection}

Soil samples $(100 \mathrm{~g})$ were gathered from several feather dumping locations and chicken farms throughout Surat, India. $\left(21.1790^{\circ} \mathrm{N}, 72.8020^{\circ} \mathrm{E}\right)$. The samples were collected and transported to the laboratory in a sterile plastic bag.

2.2 Enrichment of keratinase producing microorganisms

One gram of soil sample was mixed with $10 \mathrm{ml}$ distilled water. The mixture was shaken well and allowed to settle for 30 minutes. Five $\mathrm{ml}$ of soil supernatant inoculated in $95 \mathrm{ml}$ of whole feather basal broth medium: $\mathrm{NaCl}(0.5 \mathrm{~g} / \mathrm{L}), \mathrm{K}_{2} \mathrm{HPO}_{4}$ $(0.3 \mathrm{~g} / \mathrm{L}), \quad \mathrm{KH}_{2} \mathrm{PO}_{4} \quad(0.4 \mathrm{~g} / \mathrm{L}), \quad$ Feathers
(20g/L), pH 7.4 (Tork et al., 2010). The flasks were incubated at $37^{\circ} \mathrm{C}$ at $120 \mathrm{rpm}$.

\subsection{Isolation of keratinase producing microorganisms}

Isolation of bacteria was performed by serial dilution using nutrient agar (NA) medium (Hi-media). The enriched suspension was transferred in $10 \mathrm{ml}$ of sterilized distilled water. Aliquots, $0.1 \mathrm{ml}$ of diluted sample was inoculated in nutrient agar plates from various dilution and spread uniformly. Plates were incubated at $37^{\circ} \mathrm{C}$ for 24-48 $\mathrm{h}$. The bacterial isolates were subcultured on NA medium to obtain pure culture and maintained in NA slants at $4^{\circ} \mathrm{C}$ for further study.

\subsection{Screening of keratinolytic bacteria \\ 2.4.1 Primary screening}

The isolates were firstly inoculated on skim milk agar (SMA) plates: peptone $(5.0 \mathrm{~g} / \mathrm{L})$, yeast extract $(3.0 \mathrm{~g} / \mathrm{L})$, dextrose $(1.0 \mathrm{~g} / \mathrm{L})$, skim milk powder $(10 \mathrm{~g} / \mathrm{L})$, agar $(15 \mathrm{~g} / \mathrm{L})$, $\mathrm{pH} 7.2 \pm 0.2$. The plates were incubated at $30^{\circ} \mathrm{C}$ for $48 \mathrm{~h}$.

\subsubsection{Secondary screening for keratinase activity}

All positive primary screening isolates were subjected to secondary screening. Isolates were streaked on keratin agar (KA) plates: $\mathrm{NaCl}(0.5 \mathrm{~g} / \mathrm{L}), \mathrm{KH}_{2} \mathrm{PO}_{4}(0.7 \mathrm{~g} / \mathrm{L})$, $\mathrm{K}_{2} \mathrm{HPO}_{4}(1.4 \mathrm{~g} / \mathrm{L}), \mathrm{MgSO}_{4}, 7 \mathrm{H}_{2} \mathrm{O}(0.1 \mathrm{~g} / \mathrm{L})$, keratin powder $(10 \mathrm{~g} / \mathrm{L})$, agar $(15 \mathrm{~g} / \mathrm{L}), \mathrm{pH}$ 7.5. Plates were incubated at $37^{\circ} \mathrm{C}$ for $72 \mathrm{~h}$.

\subsection{Identification and 16S rRNA sequencing}

Identification was carried out based on colony characteristics, biochemical properties. Further confirmation of the strain was carried out using $16 \mathrm{~S}$ rRNA sequencing analysis (Saffron life science Research Pvt. Ltd, Surat, India). 


\subsection{Production of keratinase}

A $250 \mathrm{~mL}$ Erlenmeyer flask containing 90 $\mathrm{mL}$ Feather meal basal media was used to develop isolated colonies. Each flask was injected with ten millilitres of an overnight developed culture and cultured for seven days on a rotary shaker at $150 \mathrm{rpm}$. Feathers were noted to be deteriorating.

\subsubsection{Assay for keratinase activity}

The keratin digestion method was used to assess enzyme activity, with $1 \%$ keratin in $0.05 \mathrm{M}$ Tris- $\mathrm{HCl}$ buffer $(\mathrm{pH} 8.0)$ as the substrate. $1.75 \mathrm{~mL}$ substrate solution and $0.25 \mathrm{~mL}$ crude enzyme solution were used in the reaction mixtures. The reaction was stopped by adding $2.0 \mathrm{ml} \quad 0.4 \mathrm{M}$ trichloroacetic acid to the mixture and incubating it at $40^{\circ} \mathrm{C}$ in a water bath for 10 minutes (TCA). The enzyme solution was incubated with $2.0 \mathrm{ml}$ TCA without the addition of keratin as a control. After centrifuging the mixture for 30 minutes at $3825 \mathrm{rpm}$, the absorbance was measured at $280 \mathrm{~nm}$ using a spectrophotometer (Systronics) against a control. Gradiar et al., (2005) defined one unit (U/ml) of enzyme activity as a 0.01 increase in absorbance at $280 \mathrm{~nm}$ per minute under test conditions calculated using equation [1].

$\mathrm{U}=4 \times n \times A 280 /(0.01 \times 10)$

where $n$ is the dilution factor; 4 is the final reaction volume $(\mathrm{ml}) ; 10$ is the incubation time (min).

\subsubsection{Protein estimation}

Protein concentration was determined by using the Folin-Lowry Ciocalteau method. Bovine serum albumin (Hi-media) was used as a standard and the colour developed was read at $660 \mathrm{~nm}$ (Lowry et al., 1951).

\subsection{Media optimization}

\subsubsection{Inoculum preparation}

Bacterial culture was inoculated in $10 \mathrm{ml}$ nutrient broth, incubated in a shaker for 24 $\mathrm{h}$ at $37^{\circ} \mathrm{C}$ with $120 \mathrm{rpm}$ and growth obtained was inoculated in $90 \mathrm{ml}$ production media.

\subsubsection{Substrate concentration}

Different concentrations of feather viz. $0.9 \%, 1.3 \%, 1.6 \%, 1.9 \%$ and $2.2 \%$ was added in the production media. All the flasks were incubated at $37^{\circ} \mathrm{C}$ at $120 \mathrm{rpm}$. Samples were withdrawn every $24 \mathrm{~h}$ and were analysed for keratinase activity and protein content.

\subsubsection{Incubation time}

For determining the optimum time for keratinase production, the $90 \mathrm{ml}$ of production medium was inoculated with 10 $\mathrm{ml}$ of inoculum, and flasks were incubated for different time duration i.e., $24 \mathrm{~h}, 48 \mathrm{~h}$, $72 \mathrm{~h}, 96 \mathrm{~h}$ at $37^{\circ} \mathrm{C}$ at $120 \mathrm{rpm}$.

2.7.4 Effect of different nitrogen sources on keratinase production

The most suitable nitrogen source for keratinase production was determined by supplementing production media with $9 \mathrm{mg}$ of various nitrogen sources namely yeast extract, urea, peptone, and tryptone.

2.7.5 Effect of concentration of nitrogen sources

Yeast extract was the most suitable nitrogen source for keratinase production supplemented with various concentrations i.e. 8-11 mg and without nitrogen source. All the flasks were inoculated with $10 \%$ inoculum and were incubated at $37^{\circ} \mathrm{C}$ at $120 \mathrm{rpm}$ for $48 \mathrm{~h}$.

2.7.6 Effect of $\mathrm{pH}$ on the production of keratinases

Adjusting the $\mathrm{pH}$ of the production medium at $\mathrm{pH}$ ranges from 5-9. The $\mathrm{pH}$ of the production medium was adjusted with $1 \mathrm{M}$ 
$\mathrm{NaOH}$ and 1M HCL before inoculation. All the flasks were inoculated with $10 \%$ inoculum and were incubated at $37^{\circ} \mathrm{C}$ at $120 \mathrm{rpm}$ for $48 \mathrm{~h}$.

\subsection{Characterization of crude enzyme}

2.8.1 Determination of the optimum temperature

Effect of temperature on keratinase activity was checked by incubating the reaction mixture at temperature $30-60^{\circ} \mathrm{C}$ for $10 \mathrm{~min}$ and assayed for the enzyme activity.

\subsubsection{Keratinases thermal stability}

Thermal stability was examined by exposing the crude enzyme at different temperatures $30^{\circ} \mathrm{C}, 40^{\circ} \mathrm{C}, 50^{\circ} \mathrm{C}, 60^{\circ} \mathrm{C}$ for 90 min. Relative activity was calculated and $\%$ stability of the enzyme was determined.

\subsubsection{Determination of the optimum $\mathrm{pH}$}

The optimum $\mathrm{pH}$ for enzyme activity was determined by incubating the reaction mixture at various $\mathrm{pH}$ ranges from 7-10 at water bath for $10 \mathrm{~min}$ at $40^{\circ} \mathrm{C}$.

\subsection{4 pH stability}

Crude enzyme with $0.05 \mathrm{M}$ Tris-HCL buffer was incubated at various $\mathrm{pH}$ ranges from $\mathrm{pH} 7-10$ at room temperature for 90 min. The $\mathrm{pH}$ was adjusted with $1 \mathrm{M} \mathrm{NaOH}$ and 1M HCL. Relative activity was calculated and \% stability of enzyme was determined.

\subsection{Application of keratinase}

2.9.1 Keratinase enzymes as an additive in the detergents industry

Application of keratinase enzyme as a detergent additive was studied on white cotton cloth pieces $(4 \times 4 \mathrm{~cm})$ stained with human blood and coffee. Seven $\mathrm{mg} / \mathrm{ml}$ of Ariel detergent powder solutions were prepared and heated in a boiling water bath for $20 \mathrm{~min}$ to inactivate the inherent enzymes. The following sets were prepared.

Flask with distilled water $(100 \mathrm{ml})+$ stained cloth.

Flask with distilled water $(100 \mathrm{ml})+$ stained cloth $+1 \mathrm{ml}$ heat inactivated Ariel detergent $(7 \mathrm{mg} / \mathrm{ml})$.

Flask with distilled water $(100 \mathrm{ml})+$ stained cloth $+1 \mathrm{ml}$ heat inactivated Ariel detergent $(7 \mathrm{mg} / \mathrm{ml})+2 \mathrm{ml}$ of enzyme solution.

The piece of cloth was rinsed in the above flasks for $30 \mathrm{~min}$. After incubation, cloth pieces were taken out, rinsed with water, and dried. Visual examination of various pieces exhibited the effect of the enzyme in the removal of stains. Untreated cloth pieces stains were taken as control.

\subsubsection{Keratinase enzymes as animal feeds}

Degraded products of feathers were analysed for an amino acid profile by thinlayer chromatography (TLC) to analyse its potential as animal feed. In TLC, the developing solvent system was Butanol: Glacial acetic acid: water (12:3:5), and Ninhydrin solution was used as reagent (2gm of ninhydrin dissolved in $1000 \mathrm{ml}$ acetone).

\subsubsection{Keratinase enzymes as organic fertilizers}

Two pots were taken and filled with soil and marked as A and Control. The seedling of Vigna Radiate (Mung bean) was transferred to pots. In a pot, A feather hydrolysate was added and in control, tap water was added. The pots were watered every day with the sample. Analysis of plants were done at a regular interval of the day.

\subsection{Statistical analysis}


All of the analytical experiments were done twice (two sets), and statistical relevance was determined by utilising $\mathrm{R}$ studio to do one-way ANOVA and Friedman Rank Sum Test.

\section{Results}

Five samples were collected from different poultry farms and feather dumping sites. A total of 16 isolates were obtained.

\subsection{Screening of keratinolytic bacteria}

A screening program was employed to obtain bacterial isolates capable of producing feather degrading extracellular keratinase enzyme using feathers as sole carbon and nitrogen source.

\subsubsection{Primary screening}

All 16 isolates were checked for their protease activity using skim milk agar plates. Only 10 bacterial isolates showed larger zones of clearance (Figure 1). This suggested that these isolates might possess keratinase activity as well.

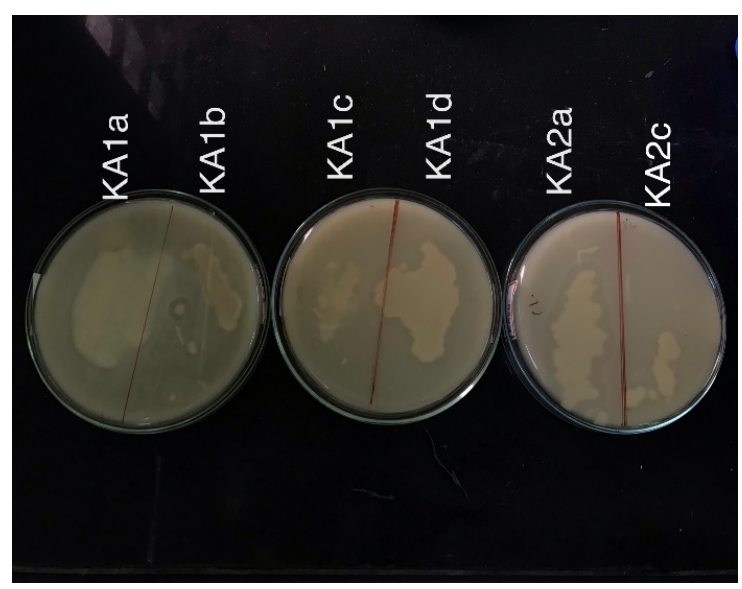

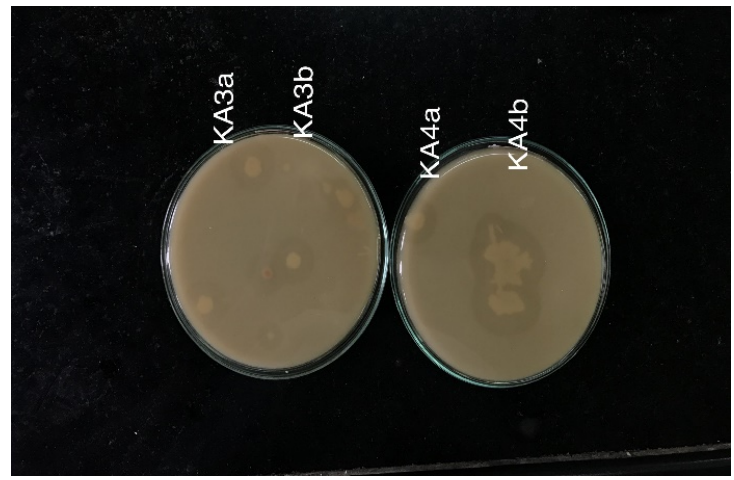

Fig. 1. Primary screening on SMA plates

\subsubsection{Secondary screening}

The above 10 isolates were grown on keratin agar plates for $24-48 \mathrm{~h}$ at $30^{\circ} \mathrm{C}$. Among 10 bacterial isolates, 9 were found as keratinase producers based on their clear zone formation on keratin agar plates (Figure 2).
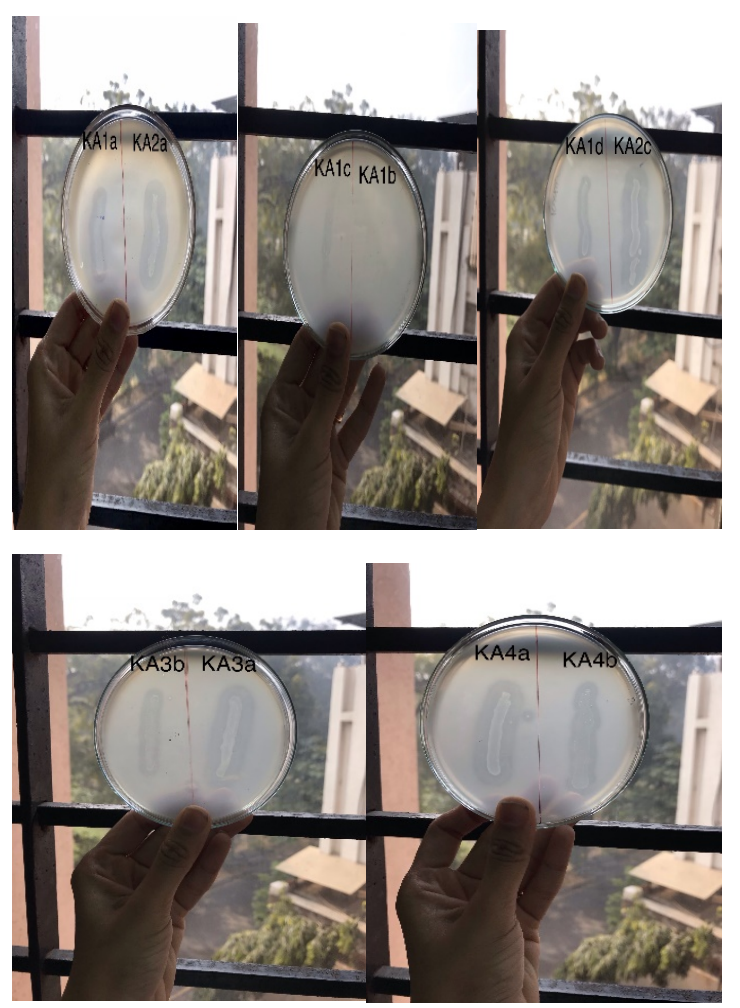

Fig. 2. Secondary screening on KA plates

The isolates that formed a definite clear zone on both the media were considered as keratinase-producing bacteria. 


\subsection{Production of keratinase enzyme}

Bacterial isolates obtained from screening were cultivated in liquid medium containing sterile feather as substrate. After 24-48 h of incubation flasks showed turbidity (Figure 3).

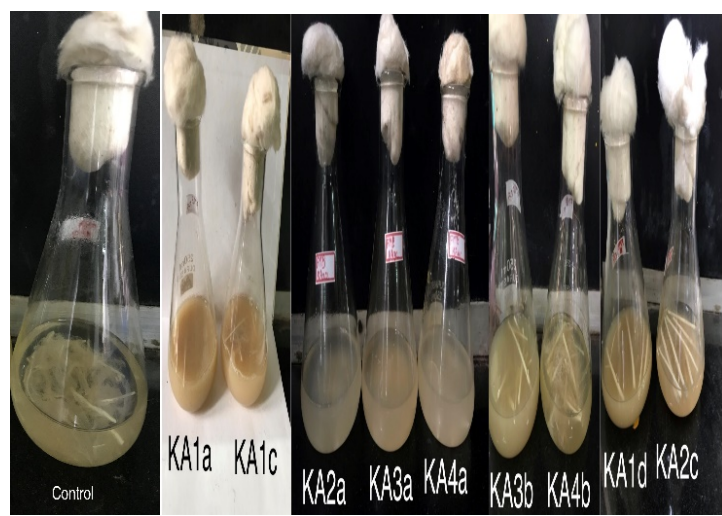

Fig. 3. Different isolates showing degradation of feathers

Degradation of feathers was visually observed.

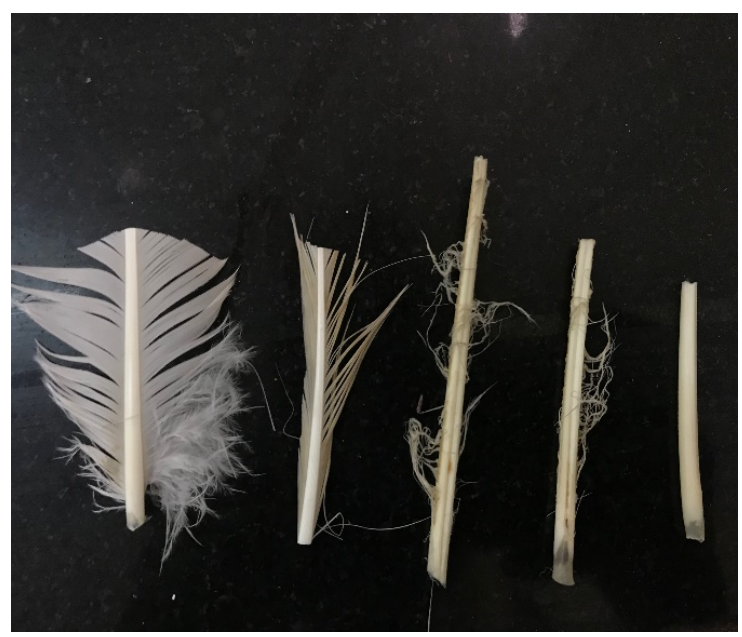

Fig. 4. Successive feather degradation

All the analysis was performed in duplicates and the mean was considered as the final value. Standard deviation value ranging up to \pm 3 was obtained throughout the studies.

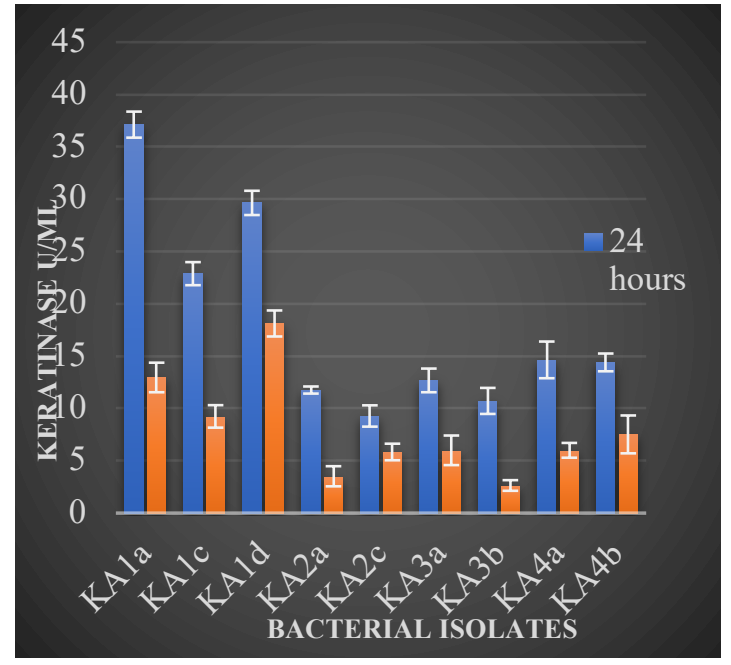

Fig. 5. Keratinase activity of different bacterial isolates. Values are means of 2 replicates \pm standard deviation.

Among all the isolated bacteria $\mathrm{KA}_{1} \mathrm{a}$, isolated from the Government of Gujarat poultry farm, Surat, India was found to be the highest keratinase producer with 37.12 $\mathrm{U} / \mathrm{ml}$ keratinase activity after $24 \mathrm{~h}$ (Figure $5)$.

\subsection{Identification and 16S rRNA sequencing}

Identification of isolate $\mathrm{KA}_{1}$ a was carried out by studying the microscopic, morphological, physiological, and biochemical characteristics. The isolate was found to be Gram-negative rod-shaped motile bacteria. Biochemical analysis showed that isolate $\mathrm{KA}_{1} \mathrm{a}$ was able to utilize citrate as well as demonstrated catalase activity.

Molecular identification performed by $16 \mathrm{~S}$ rRNA sequencing and BLAST (with the help of saffron life science) showed close identity (97\%) with Stenotrophomonas maltophilia strain NBRC 14161(Figure 6). Hence, the isolate $\mathrm{KA}_{1} \mathrm{a}$ was designated as Stenotrophomonas maltophilia. 


\section{Alignment with most coordinated sequence:}

Stenotrophomonas maltophilia strain NBRC 1416116 S ribosomal RNA, partii sequence

Sequence ID: $\underline{\text { NR } 113648.1}$ Length: 1470 Number of Matches: 1

\begin{tabular}{|l|l|l|l|l|}
\hline Score & Expect & Identities & Gaps & Strand \\
\hline 555bits(300) & $7 \mathrm{7}-158$ & $320 / 330(97 \%)$ & $0 / 330(0 \%)$ & Plus/ Plus \\
\hline
\end{tabular}

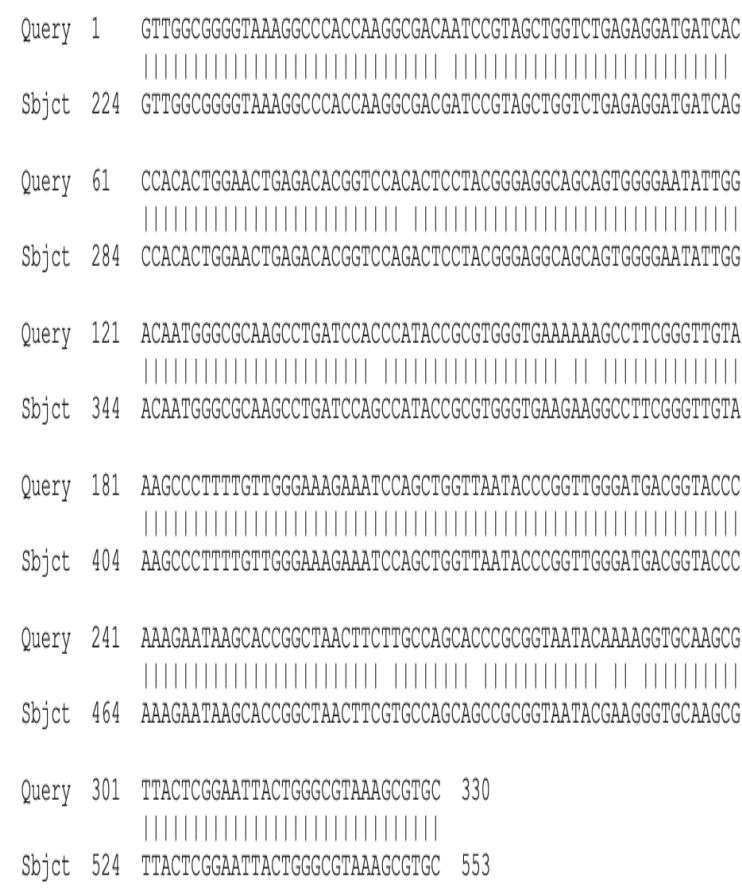

Fig. 6. 16S rRNA partial sequence

\subsection{Optimization of process parameter}

Optimization of keratinase production from the selected bacterial isolate was done by evaluating the effects of the following parameters.

\subsubsection{Substrate concentration}

Five different substrate concentrations were considered viz. 0.9,1.3,1.6,1.9 \& $2.2 \%$. The result (Figure 7(a)) depicted that an increase in keratinase yield relative to increased substrate concentration. The highest amount of keratinase was obtained with the substrate concentration of $2.2 \%$ in the production medium with $109.65 \mathrm{U} / \mathrm{ml}$ keratinase activity.
Substrate concentration is significant and was confirmed statistically by ANOVA which suggested the Degree of freedom 1, Mean sum of squares 508.9 with $\mathrm{P}$ value $0.002(<0.05)$.

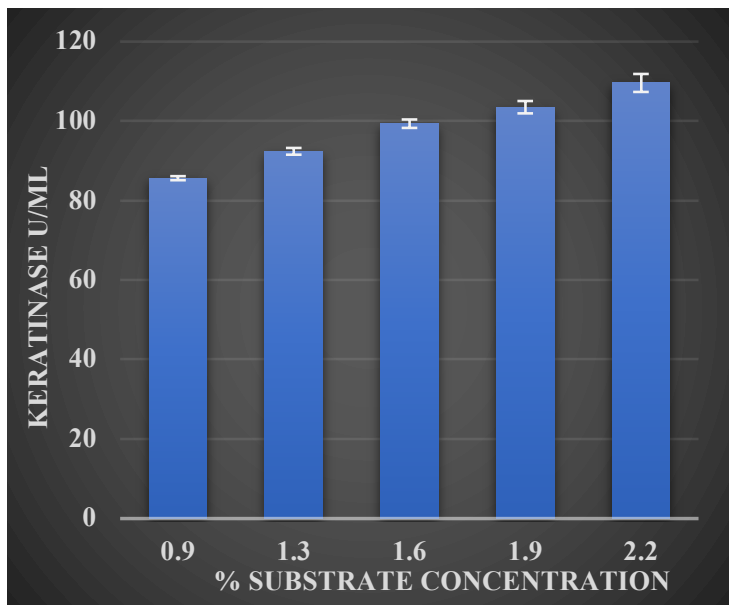

Fig. 7(a). Effect of Substrate concentration on Keratinase production. Values are means of 2 replicates \pm standard deviation.

\subsubsection{Incubation time}

The bacterial cultures were incubated at different time ranges from $24 \mathrm{~h}-96 \mathrm{~h}$. It was observed that (Figure 8) keratinase production increased within 24h. Keratinase activity $102.76 \mathrm{U} / \mathrm{ml}$ was detected at $24 \mathrm{~h}$, after which it decreased.

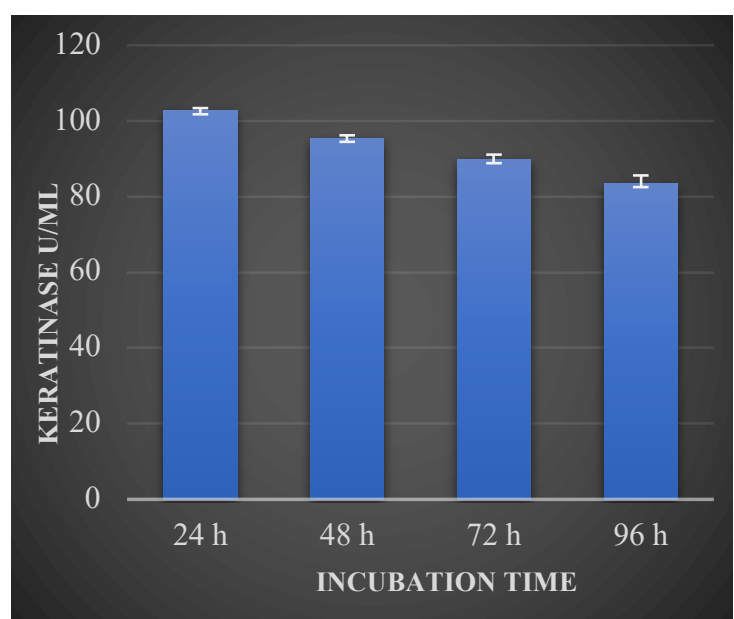

Fig. 8. Incubation time for Keratinase production. Values are means of 2 replicates \pm standard deviation. 
3.4.3 Effect of different nitrogen sources on the production of keratinases

Among various nitrogen sources viz. yeast extract, urea, peptone, and tryptone, yeast extract was the best nitrogen source for keratinase production $82.4 \mathrm{U} / \mathrm{ml}$ (Figure 9).

One-way ANOVA for statistical analysis of the effect of incubation time on keratinase production was performed and it showed that it was significant providing a $p$-value of $0.000538 \quad(<0.05)$ with a degree of freedom 3 and mean sum of square 134.17.

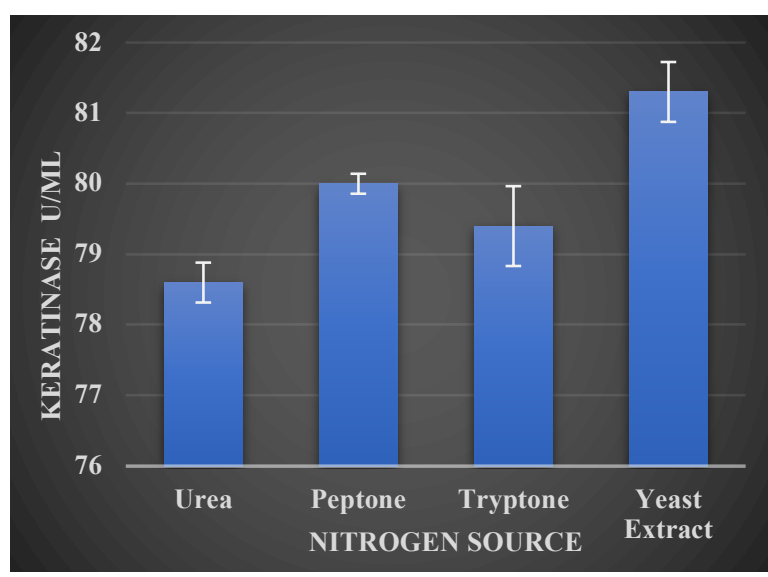

Fig. 9. Effect of nitrogen sources on Keratinase production. Values are means of 2 replicates \pm standard deviation.

\subsubsection{Effect of concentration of nitrogen} sources

The results (Figure 10) depicted an increase in keratinase yield without a nitrogen source. Feathers themselves act as nitrogen sources. The isolate accumulated the highest keratinase in the production medium having without nitrogen source with $108 \mathrm{U} / \mathrm{ml}$.

The effect of nitrogen concentration was significant which was confirmed by applying ANOVA which stated the mean sum of square 113.71 and degree of freedom 4 producing $p$-value of 0.00046 .

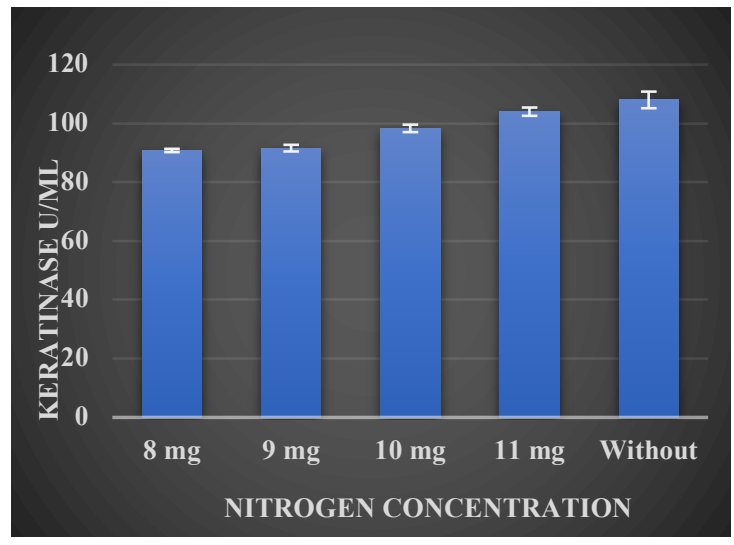

Fig. 10. Effect of nitrogen source concentration on Keratinase production. Values are means of 2 replicates \pm standard deviation.

3.4.5 Effect of $\mathrm{pH}$ on the production of keratinases

The influence of initial medium $\mathrm{pH}$ on keratinase production was analysed. At $\mathrm{pH}$ 7, the highest amount of keratinase was produced (92.84 U/ml). (Figure 11). Results of ANOVA suggested statistical relevance by generating P-value of 0.00029 $(<0.05)$, Degree of freedom 3 and Mean sum of squares 189.11 .

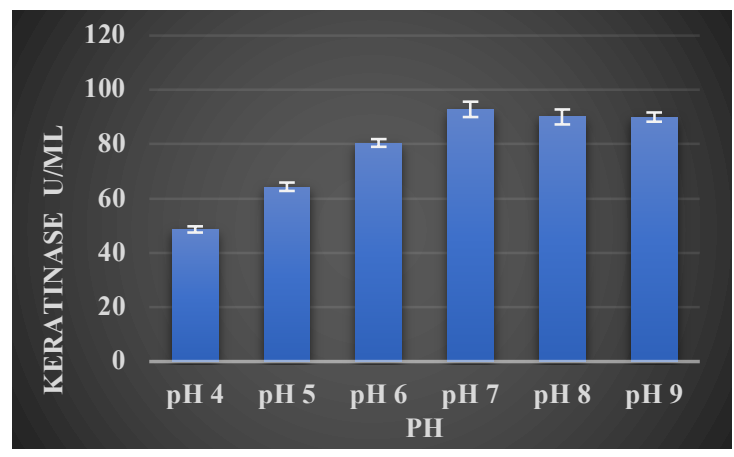

Fig. 11. Effect of $\mathrm{pH}$ on Keratinase production. Values are means of 2 replicates \pm standard deviation.

\subsection{Characterization of enzyme}

3.5.1 Determination of the optimum temperature 
Keratinase activity was observed at 30$60^{\circ} \mathrm{C}$. The optimum temperature for keratinase activity was found to be $40^{\circ} \mathrm{C}$ (Figure 12).

ANOVA for the effect of temperature on keratinase activity was suggested to be nonsignificant providing Degree of Freedom 1 and Mean sum of squares 56.69 with a p-value of 0.4 . Hence it can be stated that enzyme showed activity over a wide range of temperatures.

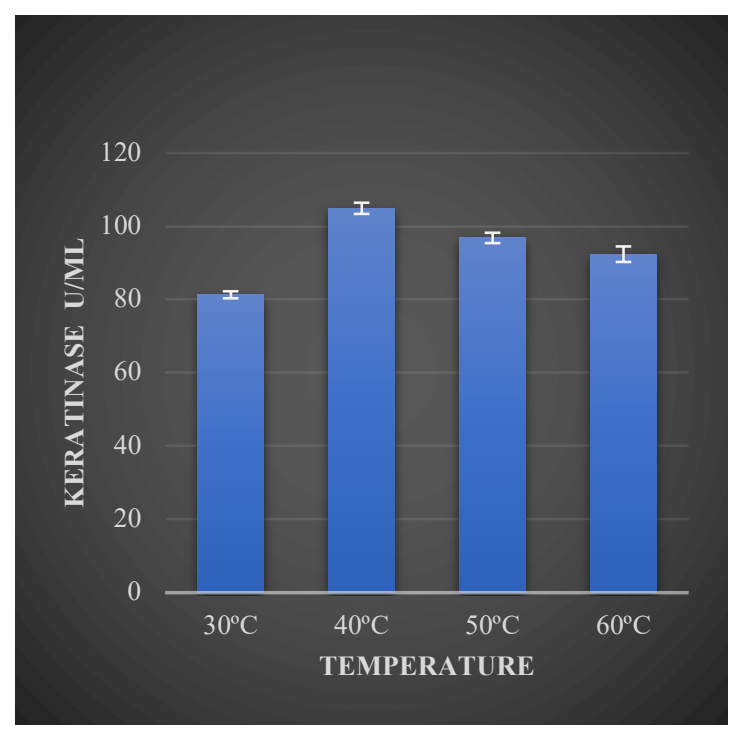

Fig. 12. Effect of temperature on keratinase activity. Values are means of 2 replicates \pm standard deviation.

\subsubsection{Keratinases thermal stability}

The activity before incubation was taken as $100 \%$. The enzyme was very stable up to $50^{\circ} \mathrm{C}$ followed by a loss of activity above $60^{\circ} \mathrm{C}$. The enzyme retained more than $90 \%$ and $80 \%$ of its activity at $40^{\circ} \mathrm{C}$ and $50^{\circ} \mathrm{C}$ (Figure 13).

Statistical analysis performed by Friedman Rank Sum Test gave the Friedman chisquared value 12 and p-value 0.007 which was less than 0.05 . Hence it was significant.

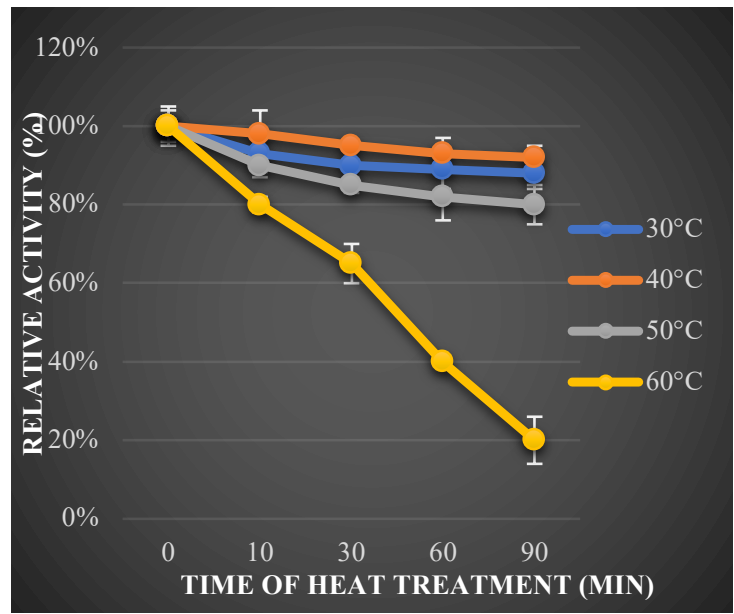

Fig. 13. Temperature stability of Keratinase. Values are means of 2 replicates \pm standard deviation.

\subsubsection{Determination of the optimum $\mathrm{pH}$}

The enzyme was most active in the $\mathrm{pH}$ range of 7.0 to 9.0 , with 7.0 being the optimal $\mathrm{pH}$. (Figure 14). The effect of $\mathrm{pH}$ on keratinase activity was found to be statistically insignificant through ANOVA by generating a p-value more than 0.05 . This can be due to the significant activity of keratinase over more than one $\mathrm{pH}$.

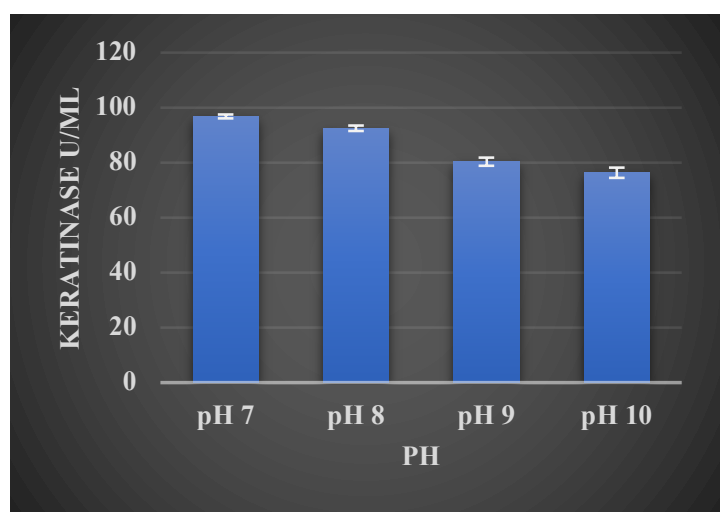

Fig. 14. Effect of $\mathrm{pH}$ on keratinase activity. Values are means of 2 replicates \pm standard deviation.

\subsection{4 pH stability}

When exposed at $\mathrm{pH} 7$, the enzyme retained $91 \%$ of its activity and maintained more than $77 \%$ of its original activity in the $\mathrm{pH}$ range 8-10 (Figure 15). Friedman Rank 
Sum Test was performed for analyzing the statistical significance of keratinase stability an over various $\mathrm{pH}$ and the results generated a p-value less than 0.05 suggesting the stability was significant.

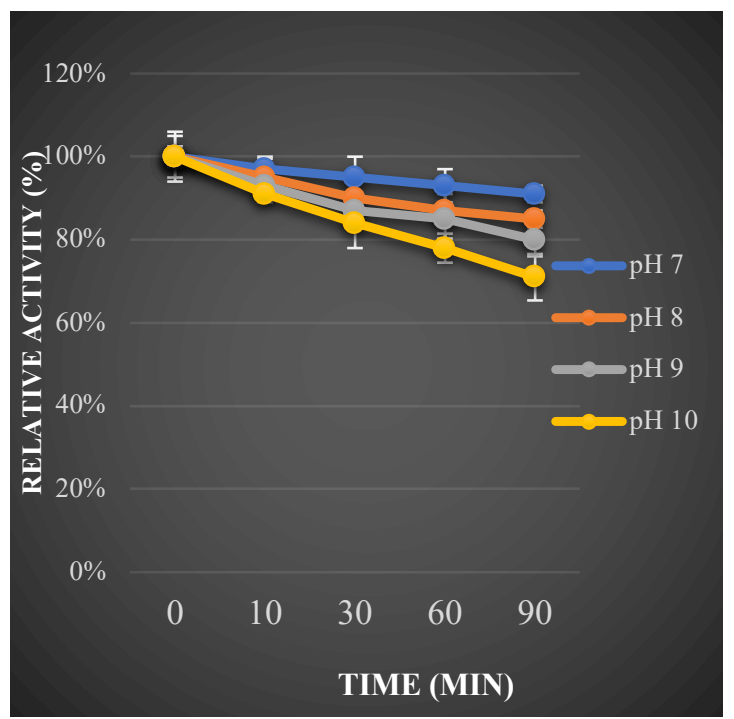

Fig. 15. $\mathrm{pH}$ stability of Keratinase. Values are means of 2 replicates \pm standard deviation.

\subsection{Application of keratinase}

3.6.1 Keratinase enzymes as an additive in the detergents industry

Visual observations were made after subjecting the stained cloth pieces to various control and test solutions (Figure $16 \mathrm{a}$ and 16b). Results indicate that keratinase was able to de-stain both blood and coffee stains on the cloth as shown in Figure $16 \mathrm{a}[\mathrm{C}]$ and Figure $16 \mathrm{~b}[\mathrm{C}]$ compared to wash performance of the detergent Figure 16a[B] and Figure 16b[B].

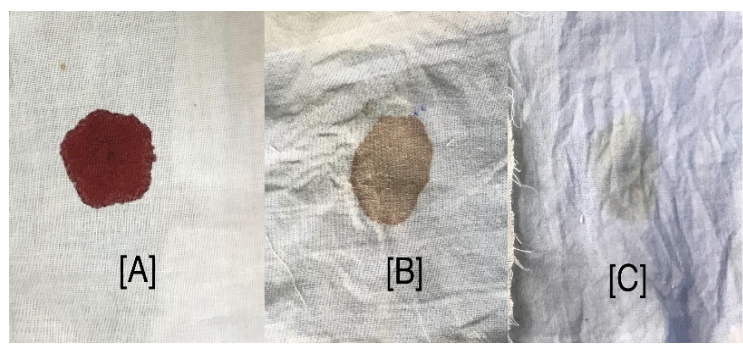

Fig. 16(a) [A] Control: bloodstain rinsed by distilled water [B] Blood +Ariel: bloodstain rinsed in Ariel detergent solution [C] Blood + Ariel + Enzyme: bloodstain rinsed by detergent followed by enzyme

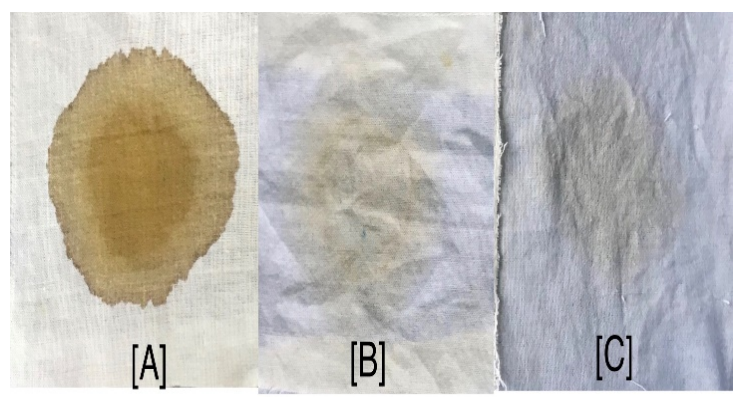

Fig. 16(b) [A] Control: coffee stain rinsed by distilled water. [B] Coffee +Ariel: coffee stain rinsed in Ariel detergent solution [C] Coffee + Ariel + Enzyme: coffee stain rinsed by detergent followed by enzyme

\subsubsection{Keratinase enzymes as animal feeds}

TLC analysis of the products of the feather degradation showed the presence of amino acids, histidine, lysine, and tryptophan (Figure 17). This was determined based on RF values.

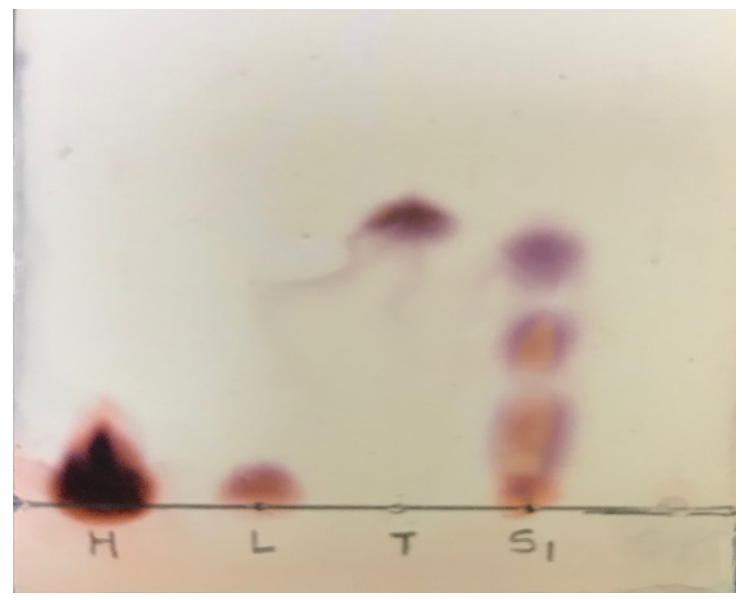

Fig. 17(a) TLC of amino acids released from degraded feathers 

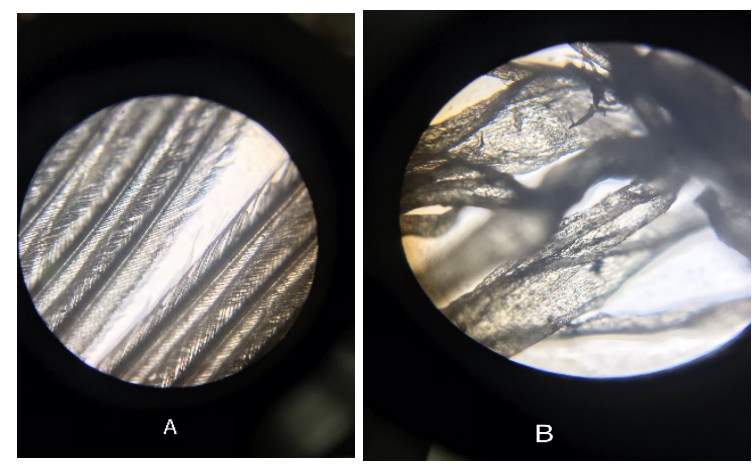

Fig. 17(b) Microscopic observation [A] Feather [B] Degraded feather

\subsubsection{Keratinase enzymes as organic} fertilizers

Effect of feather hydrolysate on the growth of Vigna radiate plant as shown in figure $18 \mathrm{a}$ and $18 \mathrm{~b}$. Results indicate that Pot A plant showed more height than control.

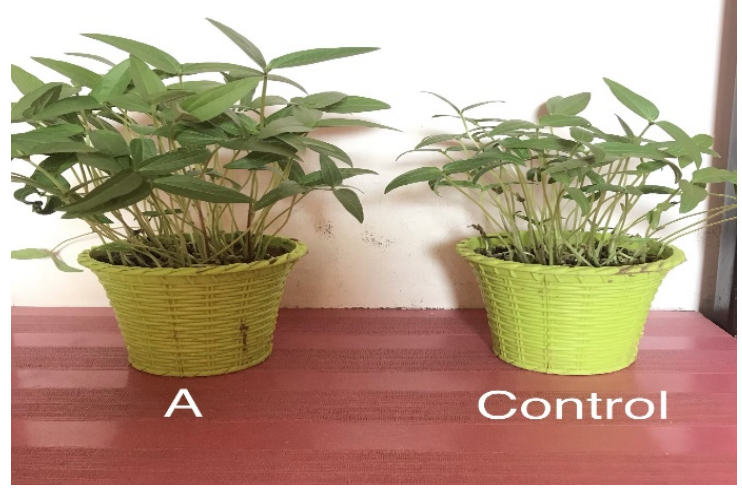

Fig. 18(a) [A] Growth of plant treated with Feather hydrolysate [Control] Growth of plant treated with tap water

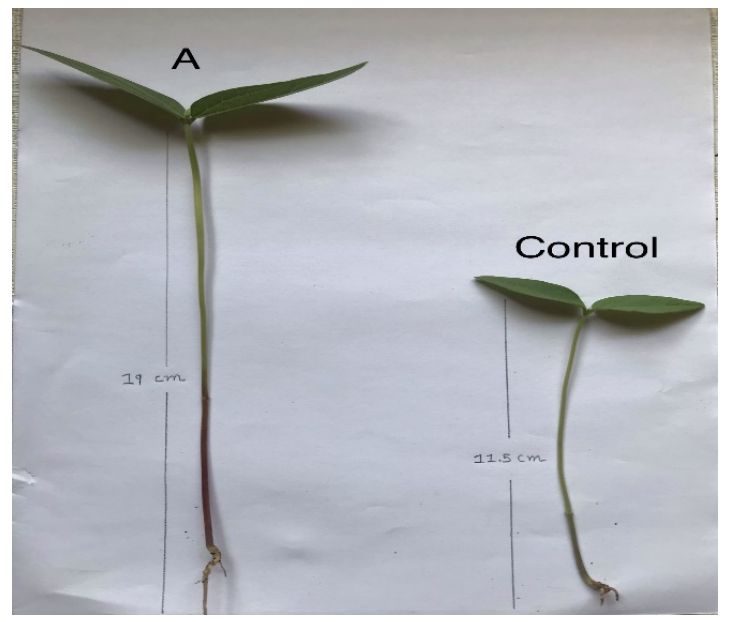

Fig. 18(b) $[A]$ Height of plant treated with feather hydrolysate [Control] Height of plant treated with tap water.

\section{Discussion}

In the current investigation, bacteria were isolated from soil samples and evaluated for keratinase production. Selected isolate $\mathrm{KA}_{1} \mathrm{a}$ was gram-negative rod-shaped bacteria and was confirmed as a strain of Stenotrophomonas maltophilia.

Stenotrophomonas maltophilia is a dominant keratinase-producing taxa. Strains of this species have been frequently isolated from poultry and feather waste dumping site which contains a rich source of the protein keratin. It is capable of the effective degradation of bird feathers and depilation of animal skins through the action of enzyme keratinase (Yamamura et al., 2002, Cao et al., 2009, Jeong et al., 2010).

The success of the microbial enzyme production process highly depends on certain Physico-chemical factors such as incubation time, substrate concentration, nitrogen source, $\mathrm{pH}$ of the medium, etc. All these factors are responsible for the optimum growth of microorganism which can directly affect enzyme production. Hence their optimum value must be determined to achieve the maximum possible enzyme yields.

Substrate concentration can be considered as one of the key factors for microbial keratinase production. It plays a dual role as carbon source as well as an inducer for enzyme production. Here feather meal because of its keratin-rich component, act as an inducer for keratinase production simultaneously along with providing carbon for growth and metabolism. Decreased substrate concentrations fail to deliver nutrients needed for appropriate growth, resulting in famine, whereas high 
feather concentrations have been shown to produce substrate inhibition or repression of keratinase production, resulting in a lower proportion of feather breakdown. Shah \& Vaidya, (2017) showed maximum keratinase production with $1 \%$ and $1.5 \%$ concentration.

Microorganisms require a suitable nitrogen source as it is an inseparable part of cellular components and biomolecules. It has been reported previously, B. pumilus FH9, Bacillus megaterium F7, and Stenotrophomonas maltophilia R13 exhibited maximum keratinase production in presence of yeast extract (El-Refai et al., 2005; Park \& son 2009; Jeong et al., 2010). In this study feathers, are a rich source of protein keratin which has a dual advantage of providing nitrogen along with the carbon for the growth of bacteria. This makes the process economical as no additional nitrogen source is required to be added to the media. Keratin in the waste chicken feathers is a cheaper alternative to peptone and also a nitrogen source for microbial growth (Akpor et al, 2018).

Changes in $\mathrm{pH}$ affect bacterial growth simultaneously with enzyme production. Moreover, it can hinder the availability of substrate for enzymes by altering their properties. Jeong et al., (2010), reported the highest keratinase production by Stenotrophomonas at $\mathrm{pH} 7.0 \mathrm{pH} 7.0$ being neutral is the most favourable $\mathrm{pH}$ for bacterial growth and hence, would have contributed to higher keratinase production.

Characterization of the enzyme leads to a determination of optimum conditions for enzyme action. Temperature and $\mathrm{pH}$ are crucial for enzyme activity. At optimum temperature and $\mathrm{pH}$, an enzyme shows maximum catalytic activity. Temperature rise beyond a certain point can cause a rapid decline in the enzyme activity decline due to enzyme denaturation. Thermal stability deciphers enzyme's ability to maintain its structure as well as activity at high temperatures. Thermostable enzymes have commercial value as they can lower the cooling cost of the process. According to Meng et al., 2013, keratinase is most active at $40^{\circ} \mathrm{C}$. Any change in $\mathrm{pH}$ has an impact on protein structure, and a drop in enzyme activity beyond its optimal $\mathrm{pH}$ could indicate deactivation or instability of the enzyme. Cai et al., (2008) reported that Microbacterium kr10 keratinase showed maximum activity at $\mathrm{pH} 7$.

Keratinase can provide a solution to waste disposal generated from poultry industries. Additionally, the protein-digesting enzyme has great potential as a detergent additive to clear the proteinic stain. Also, it can generate a mixture of amino acids, which can provide better nutrients in animal feed. The use of feather meals as animal feed has been reported (Riffel et al. 2003).

As well, it can increase the growth of plants if used as an organic fertilizer. The addition of feather hydrolysate to soil has been shown to increase urease and protease enzyme activity. Proteases and ureases in the soil play a significant role in nitrogen mineralization. Feather being rich in protein their microbial degradation in soil would release peptides and amino acids which may stimulate soil microbial activity, thereby facilitating the assimilation of nutrients by plants and better growth.

\section{Conclusion}

Among different microbial isolates screened for keratinase production using feathers, a newly isolated strain of Stenotrophomonas maltophilia with accession no. MT478451 was found to be the most potent producer. This organism was able to produce keratinase in feather basal medium supplemented with Feathers (2.2\%), $\mathrm{MgSO}_{4} .7 \mathrm{H}_{2} \mathrm{O}(1 \%), \mathrm{NaCl}(0.5 \%)$, $\mathrm{NH}_{4} \mathrm{Cl}(0.5 \%), \mathrm{K}_{2} \mathrm{HPO}_{4}(0.3 \%), \mathrm{pH}$, inoculated with $1 \% \mathrm{v} / \mathrm{v}$ pre-grown cell mass and incubated at $37^{\circ} \mathrm{C}$ under shaking conditions. Optimization studies increased 
keratinase yield by 2.9 fold giving 108 $\mathrm{U} / \mathrm{ml}$. Keratinase produced showed maximum activity at $\mathrm{pH} 7.0$ and $40^{\circ} \mathrm{C}$ and demonstrated high $\mathrm{pH}$ and temperature stability up to $90 \mathrm{~min}$. Keratinase showed promising effect with a commercial washing a detergent, animal feed, and organic fertilizer. Hence, Stenotrophomonas maltophilia $\left(\mathrm{KA}_{1} \mathrm{a}\right)$ has the potential for producing a significant amount of keratinase which possesses commercially desirable properties.

\section{References}

Adelere, I.A., \& Lateef, A. (2016). Keratinases: emerging trends in production and applications as novel multifunctional biocatalysts. Kuwait Journal of Science, 43, 118-127.

Adıgüzel, A. C., Bitlisli, B. O., Yaşa, I., \& Eriksen, N. T. (2009). Sequential secretion of collagenolytic, elastolytic, and keratinolytic proteases in peptide-limited cultures of two Bacillus cereus strains isolated from wool. Journal of Applied Microbiology, 107, 226-234.

Akhtar, W., \& Edwards, H. G. M. (1997). Fourier-transform Raman spectroscopy of mammalian and avian keratotic biopolymers. Spectrochimica Acta Part A: Molecular and Biomolecular Spectroscopy, 53, 81-90.

Akpor, O. B., Odesola, D. E., Thomas, R. E., \& Oluba, O. M. (2018). Chicken feather hydrolysate as alternative peptone source for microbial cultivation. F1000Research, 7.

Cai, C. G., Chen, J. S., Qi, J. J., Yin, Y., \& Zheng, $X$. D. (2008). Purification and characterization of keratinase from a new Bacillus subtilis strain. Journal of Zhejiang University SCIENCE B, 9, 713-720.

Cao, Z. J., Zhang, Q., Wei, D. K., Chen, L., Wang, J., Zhang, X. Q., \& Zhou, M. H. (2009). Characterization of a novel
Stenotrophomonas isolate with high keratinase activity and purification of the enzyme. Journal of Industrial Microbiology and Biotechnology, 36, 181188.

De Toni, C. H., Richter, M. F., Chagas, J. R., Henriques, J. A., \& Termignoni, C. (2002). Purification and characterization of an alkaline serine endopeptidase from a feather-degrading Xanthomonas maltophilia strain. Canadian Journal of Microbiology, 48, 342-348.

El-Refai, H. A., AbdelNaby, M. A., Gaballa, A., El-Araby, M. H., \& Fattah, A. A. (2005). Improvement of the newly isolated Bacillus pumilus FH9 keratinolytic activity. Process Biochemistry, 40, 23252332.

Feughelman M (1985) Keratin. In: Kroschwitch JI (ed) Encyclopedia of polymer science and engineering, vol 8 . Wiley, New York, pp 566-600

Gradišar, H., Friedrich, J., Križaj, I., \& Jerala, R. (2005). Similarities and specificities of fungal keratinolytic proteases: comparison of keratinases of Paecilomyces marquandii and Doratomyces microsporus to some known proteases. Applied and Environmental Microbiology, 71, 3420-3426.

Gupta, R., \& Ramnani, P. (2006). Microbial keratinases and their prospective applications: an overview. Applied Microbiology and Biotechnology, 70, 21.

Jeong, J. H., Lee, O. M., Jeon, Y. D., Kim, J. D., Lee, N. R., Lee, C. Y., \& Son, H. J. (2010). Production of keratinolytic enzyme by a newly isolated featherdegrading Stenotrophomonas maltophilia that produces plant growth-promoting activity. Process Biochemistry, 45, 17381745 . 
Kumar, R., Balaji, S., Uma, T. S., Mandal, A. B., \& Sehgal, P. K. (2010). Optimization of influential parameters for extracellular keratinase production by Bacillus subtilis (MTCC9102) in solid state fermentation using horn meal—a biowaste management. Applied Biochemistry and Biotechnology, 160, 30.

Lateef, A., Oloke, J. K., Kana, E. G., Sobowale, B. O., Ajao, S. O., \& Bello, B. Y. (2010). Keratinolytic activities of a new feather-degrading isolate of Bacillus cereus LAU 08 isolated from Nigerian soil. International Biodeterioration \& Biodegradation, 64, 162-165.

Lowry, O. H., Rosebrough, N. J., Farr, A. L., \& Randall, R. J. (1951). Protein measurement with the Folin phenol reagent. Journal of Biological Chemistry, 193, 265-275.

Meng, J., Xing, L., \& Zhao, X. (2013). Isolation of a feather-degrading Bacillus subtilis strain from the alimentary tract of grebes. African Journal of Microbiology Research, 7, 2550-2559.

Park, G. T., \& Son, H. J. (2009). Keratinolytic activity of Bacillus megaterium F7-1, a feather-degrading mesophilic bacterium. Microbiological Research, 164, 478-485.

Riffel, A., Lucas, F., Heeb, P., \& Brandelli, A. (2003). Characterization of new keratinolytic bacterium that completely degrades native feather keratin. Archives of Microbiology, 179, 258-265.

Saibabu, V., Niyonzima, F. N., \& More, S. S. (2013). Isolation, partial purification and characterization of keratinase from Bacillus megaterium. International Research Journal of Biological Sciences, 2, 13-20.
Shah, M., \& Vaidya, R. (2017). Partial characterization of keratinase from Stenotrophomonas maltophilia K279a and study of its dehairing potential. International Journal of Biotechnology and Biochemistry, 13, 95-110.

Tork, S., Aly, M. M., \& Nawar, L. (2010). Biochemical and molecular characterization of a new local keratinase producing Pseudomomanas sp., MS21. Asian Journal of Biotechnology, 2, $1-13$.

Yamamura, S., Morita, Y., Hasan, Q., Yokoyama, K., \& Tamiya, E. (2002).

Keratin degradation: a cooperative action of two enzymes from Stenotrophomonas sp. Biochemical and Biophysical Research Communications, 294, 1138-1143.

$\begin{array}{lr}\text { Submitted: } & 07 / 09 / 2020 \\ \text { Revised: } & 08 / 10 / 2020 \\ \text { Accepte: } & 26 / 10 / 2020 \\ \text { DOI: } & 10.48129 / \text { kjs.v48i4 } 9973\end{array}$

